\title{
Potential of Open-Air Hydroponic System in Producing Highly Nutritional Composition Maize Fodder for Goat Farming
}

\author{
Whay Chuin Lim¹, Mohd Noor Hisham Mohd Nadzir ${ }^{1 *}$, Mark Wen Han Hiew², \\ Md. Shuhazlly Mamat ${ }^{3}$, Muhamad Hazim Nazli ${ }^{4}$ and Shamarina Shohaimi ${ }^{1}$
}

${ }^{1}$ Department of Biology, Faculty of Science, Universiti Putra Malaysia, 43400 UPM Serdang, Selangor, Malaysia

${ }^{2}$ Department of Veterinary Clinical Studies, Faculty of Veterinary, Universiti Putra Malaysia, 43400 UPM Serdang, Selangor, Malaysia

${ }^{3}$ Department of Physics, Faculty of Science, Universiti Putra Malaysia, 43400 UPM Serdang, Selangor, Malaysia

${ }^{4}$ Department of Crop Science, Faculty of Agriculture, Universiti Putra Malaysia, 43400 UPM Serdang, Selangor, Malaysia

\section{ABSTRACT}

This study aimed to identify the chemical composition of hydroponic maize fodder (HMF) from two varieties of maize grains (popcorn and feed corn). A completely randomized design (CRD) with three replications was used in which popcorn was irrigated with clean tap water (T1) and nutrient solution (T2); feed corn irrigated with clean tap water (T3) and nutrient solution (T4). Seven-days green fodders were sampled for chemical analysis. The crude protein $(\mathrm{CP})$ content was the highest at $7.48 \%$ in T4 compared to popcorn $(P<0.05)$ and T3 $(P>0.05)$. Treatment 3 showed the highest dry matter content as $94.42 \%(P>0.05)$ and

ARTICLE INFO

\section{Article history:}

Received: 9 September 2021

Accepted: 5 October 2021

Published: 21 December 2021

DOI: https://doi.org/10.47836/pjtas.45.1.07

E-mail addresses:

whay.chuin@gmail.com (Whay Chuin Lim)

mnhisham@upm.edu.my (Mohd Noor Hisham Mohd Nadzir)

mark@upm.edu.my (Mark Wen Han Hiew)

shuhazlly@upm.edu.my (Md. Shuhazlly Mamat)

m_hazim@upm.edu.my (Muhamad Hazim Nazli)

shamarina@upm.edu.my (Shamarina Shohaimi)

*Corresponding author organic matter content observed as $98.29 \%$ especially compared with T1 $(P<0.05)$. The neutral detergent fiber (NDF) and acid detergent fiber (ADF) contents of feed corn were insignificantly different, but T3 was observed as $67.66 \%$ and $41.55 \%$, respectively, which were higher than $\mathrm{T} 1$ $(P<0.05)$. Although feed corn had better nutritional value than popcorn, popcorn showed a $7 \%$ higher germination rate than 
feed corn $(P<0.05)$. As a result, the total yield of $1.5 \mathrm{~kg}$ hydroponic maize fodder per $\mathrm{kg}$ feed corn was lower than popcorn $(2.5$ $\mathrm{kg}$ per $\mathrm{kg}$ grains). Hence, popcorn was used to grow HMF with the open-air hydroponic system. HMF showed better feed nutritive composition than conventionally planted Napier grass. A lower concentration of indigestible fiber $(P<0.05)$ and a higher concentration of crude protein (12.28\%) was observed in HMF compared to CP in Napier grass $(7.22 \%)(P<0.05)$. In conclusion, the open-air hydroponics system can be an alternative method among smallholders by replacing conventionally planted fodder.

Keywords: Feed corn, Napier grass, nutrient solution, open-air hydroponic system, popcorn

\section{INTRODUCTION}

Most livestock farmers in Malaysia are smallholders prone to providing low quality and quantity of feed, which unavoidably leads to low productivity. There is less concern for nutritional management due to limited time, cost constraints, and labor issues (Ghani et al., 2017). The challenges faced by smallholder farmers include the reduced pasture area and unavailability of land for fodder cultivation, forcing them to rely more on concentrates than roughage, which increases production costs. Hence, a proper feeding regime is importantly provided and implemented for the requirement of goats to support optimal farm production and be economical.
Automated and mechanized intensive production systems such as hydroponics technology were recently introduced as future alternative growing fodder for livestock. The hydroponic technology embodies the concept of 'owner-operator', which means a smallholder typically runs the farm's day-to-day operations. Hence, much research has implemented the suggestion of growing different fodder crops through hydroponic technology, including barley (Fazaeli et al., 2012); oats, wheat (Kantale et al., 2017); sorghum, alfalfa, cowpea (AlKaraki \& Al-Hashimi, 2012); and maize (Naik et al., 2014). This system has been highlighted as a cost-effective method due to its ability to increase fodder production with minimal land or space, water, and labor (Al-Karaki \& Al-Hashimi, 2012). In addition, high digestibility and crude protein contents make hydroponic fodder suitable for ruminants (Naik et al., 2014).

In Malaysia, a commercial hydroponic fodder system hailed as "landless fodder production" was introduced by a foreign company. The system's performance was conducted at Universiti Putra Malaysia (UPM) in 1996 to produce feed for animals that required high energy feed, such as horses and ruminants (Abdullah, 2001). The barley grass was hydroponically germinated and grown in this imported environmentally controlled cabin. However, the commercial marketability of the imported system is directed mainly at high-value animals, such as equines and livestock producing highvalue products, including high producing 
dairy cows, milk goats, and deer (Francis et al., 2018; Naik et al., 2015), resulting in the limited literature published that solely address hydroponic fodder for goat. Although research in hydroponic fodder has increased, further research is needed to develop low-cost devices for hydroponic fodder production using locally available materials on different livestock categories.

In this study, maize grains were the choice of hydroponics fodder production due to their easy availability, good biomass production, and quick growing habit. As the productivity of the livestock in a farm is highly dependent on the nutritive value of the fodder, this study was conducted to evaluate the nutritive value of maize grains to produce hydroponics fodder.

\section{METHODOLOGY}

\section{Selection of Maize Grains for Hydroponic Maize Fodder}

The preliminary study used twelve polyethylene trays sized $44 \mathrm{~cm}$ width $\mathrm{x} 34$ cm length $x 5 \mathrm{~cm}$ depth with holes at the base to allow excess water drainage from irrigation based on a completely randomized design. Two varieties of maize grains were purchased from different sources: popcorn from Kinghin Sdn. Bhd. (baking ingredients and packaging supplier company located at Melaka, Malaysia) and feed corn from Ng Sing Heng Sdn. Bhd. (store wholesaler located at Jalan Lorong Pandan, Melaka, Malaysia). Both grains were cleaned, treated, and sprouted into HMF described by Morgan et al. (as cited in Naik et al., 2015, p. 3).

There were two different irrigation treatments for each variety of maize grains. It led to the formation of four treatments groups: two groups were popcorn irrigated with tap water, which is free from additives (T1) and nutrient solution (T2); another two groups were feed corn irrigated with clean tap water (T3) and nutrient solution (T4). Treatment groups T2 and T4 were irrigated with tap water for the first three days, and the nutrient solution was used from day 4 to day 7 (Morgan et al. as cited in Naik et al., 2015, p. 3). The nutrient solution was prepared using the chemically based hydroponic solutions purchased from Nursery Petani Kota, Selangor, Malaysia. All maize grains were manually irrigated using a plastic sprayer (2 liters) hourly from 0700 to 1900 . The growth of hydroponic maize fodders (HMF) sprouted from two varieties of maize grains was summarized in Table 1. 
Germination Test. A paper towel was placed in a plastic tray sized $44 \mathrm{~cm}$ width $\mathrm{x}$ $34 \mathrm{~cm}$ length $x 5 \mathrm{~cm}$ depth and moistened with water until it was thoroughly damp. A total of 100 seeds were placed in rows on the towel. Another paper towel was loosely placed onto the first paper towel and moistened, leaving the seeds sandwiched between the two towels. The substrates were kept closed and placed in an area out of direct sunlight that stays at room temperature (International Seed Testing Association [ISTA], 2016). After the sevenday germination period, the paper towel at the top was removed, and the seedlings that had shoots longer than $1 \frac{1}{2}$ inches (and at least one firm root) were counted as viable seeds in the germination rate. The germination rate was determined through the formula below:

$$
\text { Germination rate }(\%)=\frac{\text { Number of germinating seeds }}{\text { Total number of seeds tested }} \times 100
$$

Conversion Ratio. The biomass production produced per unit of seed used (Peer \& conversion ratio was based on fresh fodder Leeson, 1985).

$$
\text { Conversion ratio }=\frac{\text { Fresh weight of green fodder }(\mathrm{kg})}{\text { Fresh weight of seed used }(\mathrm{kg})}
$$

\section{Open-Air Hydroponic System}

A used cattle pen-sized $35 \mathrm{ft}$ width and 27 $\mathrm{ft}$ length were sheltered with polyethylene sunshade netting to protect green fodders from heat before installing the openair hydroponic fodder growing system (Figure 1). The cattle pen was also fenced with galvanized welded iron wire mesh (bottom) and zinc sheet (top) as a protective measurement from rodents. Two water tanks were used as the water storage system: Tank 1 was fed by clean tap water, and Tank 2 was fed by water from an outlet at the bottom of Tank 1 (Figure 2). Two centrifugal pumps (Model CPM-158, AC $200-240$ V 50 $\mathrm{Hz}, \mathrm{Victa}^{\mathrm{TM}}$, Malaysia) connected to Tank
2 pumped water to a filter and then to the water channels (Figure 3). Polyethylene pipes sized $25 \mathrm{~mm}$ were used as waterconducting networks from tanks, centrifugal pumps, filters, and water channels. The water channels drained water into eleven water ducts composed of polyethylene pipes sized $16 \mathrm{~mm}$. The water flow of five ducts was drained from Pump 1 and another six ducts from Pump 2. The water ducts were spaced $2 \mathrm{ft}$ apart, and plastic misting spray nozzles were placed at 2-ft intervals along these water ducts (Figure 4).

Polyethylene trays sized $52.0 \mathrm{~cm}$ length $\times 32.0 \mathrm{~cm}$ width $\times 2.5 \mathrm{~cm}$ height with holes at the base to allow excess water drainage 
from irrigation was used. The HMF was grown for seven days, as shown in Figure 5. All grains were washed and soaked for four hours in tap water (Morgan et al., cited in Naik et al., 2015, p. 3). After 24 hours of germination covered with wet cloths, sprouted grains were spread on the hydroponic trays at a rate of $1 \mathrm{~kg}$ per tray. Seven days were considered to evaluate the trays produced quality hydroponic fodder (Naik et al., 2015). No supplemental light was used for this hydroponics system due to the high availability of sunlight that Malaysia experiences per year. Photosynthesis is not dominant for the seedling's metabolism until the end of day 5, when the chloroplasts are activated (Sneath \& Mclntosh, 2003).
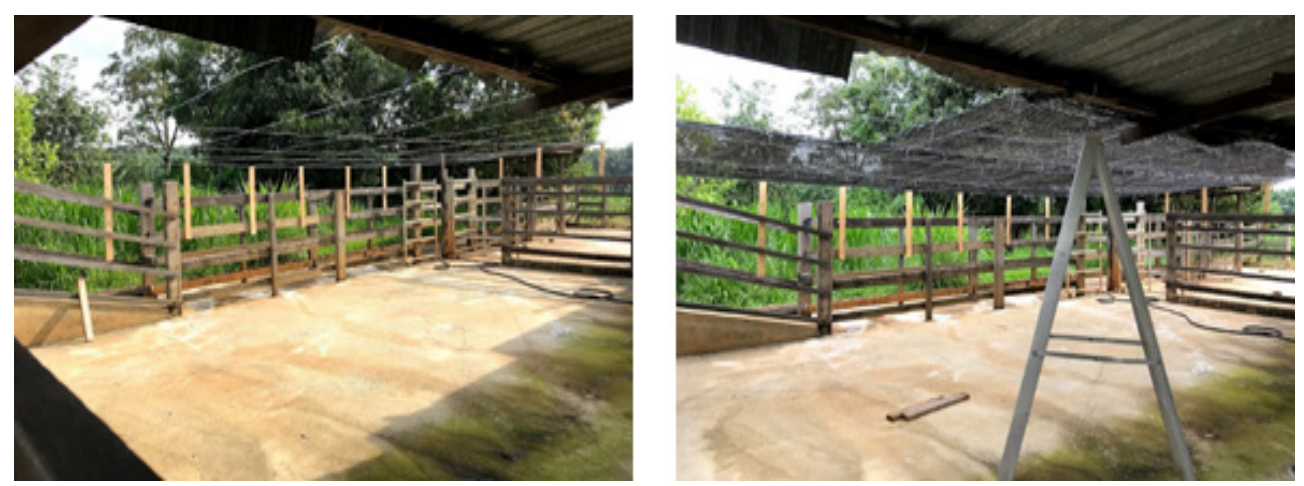

Figure 1. A used cattle pen was transformed into the open-air hydroponic green fodder growing system

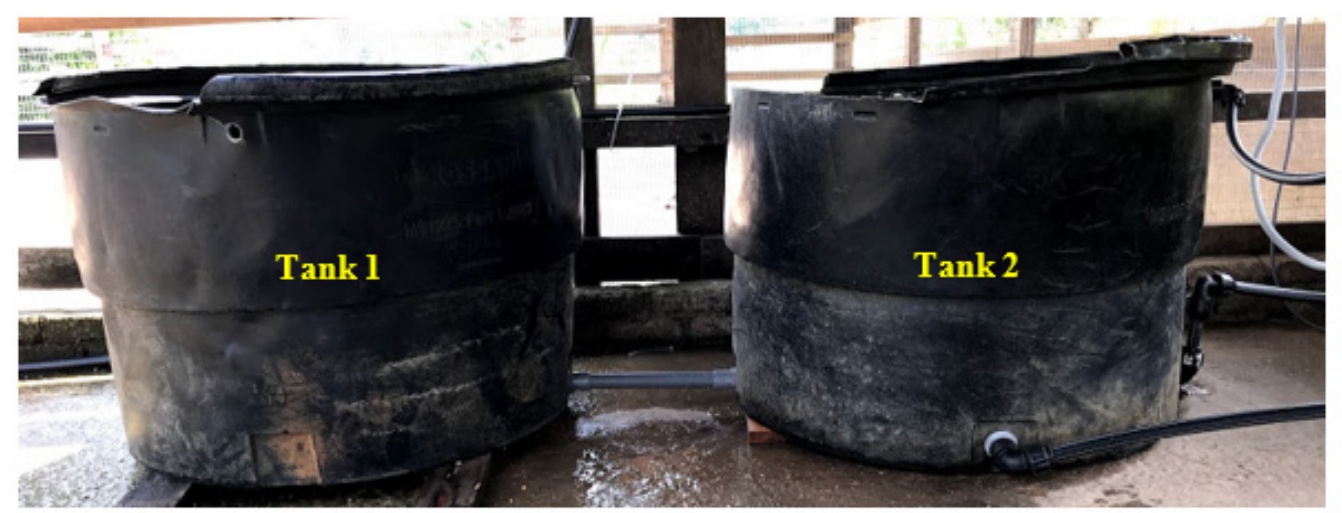

Figure 2. A two-tanks system was applied to ensure a continuous supply of water 


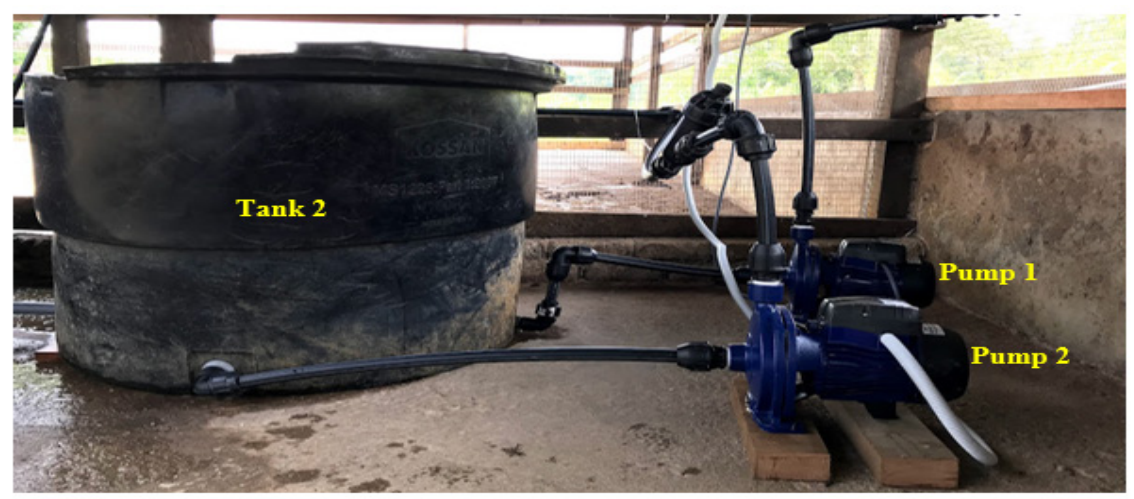

Figure 3. The water-conducting network from Tank 2, two centrifugal pumps and filters

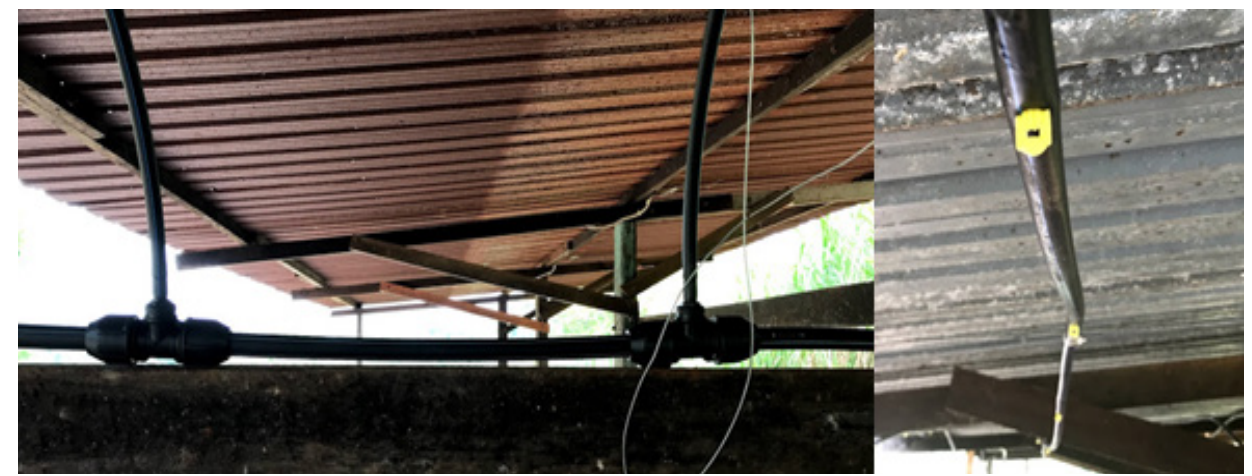

Figure 4. Distance between water ducts, which were smaller diameter than water channels (left), and the placement of misting spray nozzles along the water ducts (right)

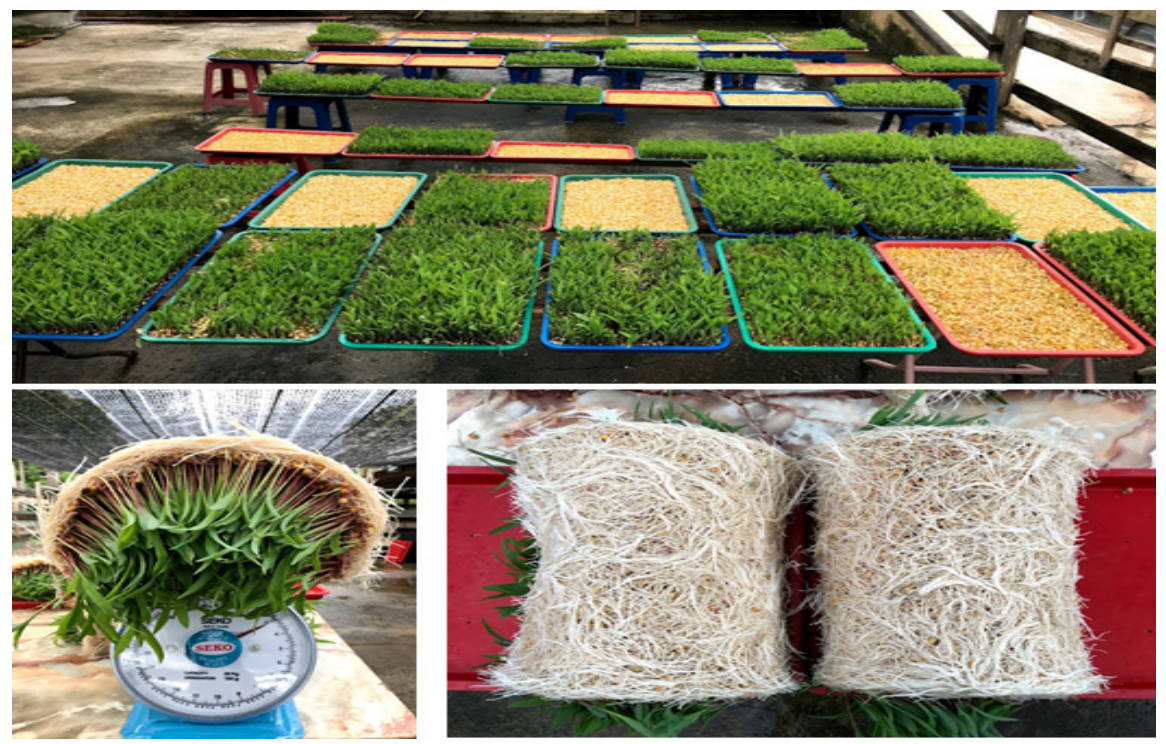

Figure 5. The hydroponic maize fodder, which was grown for seven days 
Whay Chuin Lim, Mohd Noor Hisham Mohd Nadzir, Mark Wen Han Hiew, Md. Shuhazlly Mamat, Muhamad Hazim Nazli and Shamarina Shohaimi

\section{Napier Grass}

The conventional green fodder, Napier grass (Penniseutm puprpureum), was already planted at the farm and fertilized with goat manure. The grass was harvested daily from the pasture (8-10 weeks). Napier grass was harvested at about 1.0-1.5 $\mathrm{m}$ height and then chopped to a size of about $3-5 \mathrm{~cm}$ using a fuel-driven chopper machine.

\section{Chemical and Statistical Analysis}

The fresh fodders were weighed and sampled to measure the fresh yield and estimate the conversion ratio. The representative samples (200 $\mathrm{g}$ each) of each green fodder were ovendried at $60^{\circ} \mathrm{C}$ for 48 hours, ground to pass a 1-mm mesh screen sieve, and stored for chemical analysis. The nutritive values were determined by near-infrared spectroscopy (NIRS) (Model DS2500, FOSS, Denmark) with additional calibration from the fodder samples analyzed using standard laboratory procedure. The amount of crude protein $(\mathrm{CP})$ was measured and calculated $(\mathrm{N}$ x 6.25) (Association of Official Analytical Chemists [AOAC], 1990). The neutral detergent fiber (NDF) and acid detergent fiber (ADF) were determined using FiberCap 2023 System (FOSS, Denmark) (International Organization for Standardization [ISO], 2008).

The chemical compositions between two types of green fodders were compared using the independent sample $t$-test. In addition, the nutritive value of hydroponically sprouted maize fodder from two varieties of maize grains (popcorn and feed corn) was statistically analyzed using a one- way analysis of variance (ANOVA) with a significant level $P<0.05$. Finally, the significant differences between the mean were determined using the least significant difference (LSD) test. All the values from the results were stated as mean \pm standard error of means (SEM).

\section{RESULTS AND DISCUSSION}

\section{Selection of Maize Grains for Hydroponic Maize Fodder}

All HMF were harvested on day seven and chemically analyzed (Table 2). There was no statistical difference in dry matter (DM) content between treatment groups. The popcorn (T1) and feed corn (T3) irrigated with clean tap water showed slight elevation with no significant difference of DM content as compared to popcorn (T2) and feed corn (T4) irrigated with nutrient solution. However, the CP content of the sprouted feed corn was higher than that of popcorn, especially the feed corn irrigated with nutrient solution (7.48\%). Meanwhile, the organic matter (OM) content ranged from the least $(93.71 \%)$ in $\mathrm{T} 1$ to the highest $(98.29 \%)$ in T3 $(P<0.05)$. At the same time, the lowest fibers content indicated by NDF and ADF was recorded from feed corn (T4) irrigated with the nutrient solution with an average of $67.40 \%$ and $40.95 \%$, respectively. A germination test (ISTA, 2016) of both maize grains using tap water irrigation (T1 and T3) was recorded in Table 3. Popcorn showed a higher germination rate for the seven-day germination period, which was $7 \%$ higher than feed corn $(84.3$ \%) $(P<0.05)$. 
By the end of the seven-day germination cycle, the hydroponics green fodder had grown into a mat of $15-23 \mathrm{~cm}$ in height, with germinated seeds embedded in white roots and green shoots. For the same sprouting time, the forage mat had reached a height of 20 to $30 \mathrm{~cm}$, depending on the grain types (Naik et al., 2015). The yields ranged from 3.5 to 6.0 folds on a fresh basis with DM content of $11-14 \%$ are expected for hydroponics maize fodder or hydroponically sprouted maize grains (Naik et al., 2014). Similarly, there are reports of a 3.7-4.5 times increase in the fresh weight with DM content of $19.26-19.7 \%$ in 6-7 days of hydroponics barley fodder (Dung et al., 2010; Fazaeli et al., 2011). Nevertheless, an earlier study obtained a ratio of 2.76 to $3 \mathrm{~kg}$ green fodder per $\mathrm{kg}$ of barley seed (Al-Ajmi et al., 2009). There are several affecting factors of the biomass production conversion ratio, including management, amount, and frequency of irrigation, usage of nutrient solution, climate (temperature and humidity), density, and position of lights, type, and quality of the grain, a load of seeds on each tray and growth period (Hubballi et al., 2010; Molla \& Birhan, 2010; Trubey et al., 1969).

Table 2

Chemical composition of two varieties of maize grains irrigated with tap water and nutrient solutions

\begin{tabular}{lcccc}
\hline $\begin{array}{l}\text { Parameters } \\
(\% \text { of DM })\end{array}$ & \multicolumn{4}{c}{ Treatment groups } \\
\cline { 2 - 5 } & $\mathrm{T} 1$ & $\mathrm{~T} 2$ & $\mathrm{~T} 3$ & $\mathrm{~T} 4$ \\
\hline $\mathrm{n}=12$ & $\mathrm{n}=12$ & $\mathrm{n}=12$ & $\mathrm{n}=12$ \\
$\mathrm{DM}$ & $92.03 \pm 0.13$ & $91.27 \pm 1.09$ & $94.42 \pm 0.13$ & $91.59 \pm 3.85$ \\
$\mathrm{CP}$ & $7.10 \pm 0.01^{\mathrm{a}}$ & $7.37 \pm 0.01^{\mathrm{ab}}$ & $7.42 \pm 0.00^{\mathrm{bc}}$ & $7.48 \pm 0.01^{\mathrm{c}}$ \\
$\mathrm{OM}$ & $93.71 \pm 0.99^{\mathrm{a}}$ & $96.69 \pm 0.48^{\mathrm{ab}}$ & $98.29 \pm 0.13^{\mathrm{b}}$ & $97.24 \pm 0.78^{\mathrm{ab}}$ \\
$\mathrm{NDF}$ & $70.62 \pm 0.08^{\mathrm{c}}$ & $69.70 \pm 0.11^{\mathrm{bc}}$ & $67.66 \pm 00.05^{\mathrm{ab}}$ & $67.40 \pm 0.06^{\mathrm{a}}$ \\
$\mathrm{ADF}$ & $42.30 \pm 0.04^{\mathrm{b}}$ & $41.56 \pm 0.13^{\mathrm{a}}$ & $41.55 \pm 0.04^{\mathrm{a}}$ & $40.95 \pm 0.07^{\mathrm{a}}$ \\
\hline
\end{tabular}

Note. $\mathrm{T} 1=$ Popcorn irrigated with tap water; $\mathrm{T} 2=$ Popcorn irrigated with the nutrient solution; $\mathrm{T} 3=$ Feed corn irrigated with tap water; T4 = Feed corn irrigated with the nutrient solution; $\mathrm{DM}=$ Dry matter; $\mathrm{CP}=\mathrm{Crude}$ protein; $\mathrm{OM}=$ Organic matter; $\mathrm{NDF}=$ Neutral detergent fiber; $\mathrm{ADF}=$ Acid detergent fiber; $\mathrm{n}=$ Number of samples; All analyses are mean \pm standard error of means (SEM); a,b,c $=$ Means with different superscripts within a row are significantly different $(P<0.05)$ 
Table 3

Comparisons of germination rate (\%) of popcorn and feed corn irrigated with tap water

\begin{tabular}{ccc}
\hline Growth period (days) & Popcorn & Feed corn \\
\hline 1 & $\mathrm{n}=100$ & $\mathrm{n}=100$ \\
2 & $84.7 \pm 0.88^{\mathrm{a}}$ & $57.7 \pm 1.20^{\mathrm{b}}$ \\
3 & $88.3 \pm 0.88^{\mathrm{a}}$ & $74.0 \pm 1.15^{\mathrm{b}}$ \\
4 & $89.7 \pm 0.67^{\mathrm{a}}$ & $80.3 \pm 0.88^{\mathrm{b}}$ \\
5 & $89.7 \pm 1.20^{\mathrm{a}}$ & $83.7 \pm 0.33^{\mathrm{b}}$ \\
6 & $91.7 \pm 0.67^{\mathrm{a}}$ & $83.7 \pm 1.20^{\mathrm{b}}$ \\
7 & $91.7 \pm 0.88^{\mathrm{a}}$ & $84.0 \pm 0.58^{\mathrm{b}}$ \\
\hline
\end{tabular}

Note. $\mathrm{n}=$ Number of samples; All analyses are mean \pm standard error of means (SEM); Means with different superscript letters in a row are significantly different $(P<0.05)$

The popcorn (T1) and feed corn (T3) irrigated with tap water expressed an insignificant higher DM content compared to the other HMF irrigated with nutrient solution (T2 and T4). Dung et al. (2010) reported a similar finding that the use of nutrient solution lowers the DM loss, which may be due to the absorption of minerals, thus increasing the ash content and the final weight of the hydroponics fodder. Besides, the DM loss could be due to the significant water uptake during germination and vegetation (Naik et al., 2015). The more significant dry weight losses and increasing trend in protein content could be attributed to the loss of dry weight, particularly carbohydrates, via respiration during germination. In a sevenday sprout, scarcity of time for significant DM accumulation due to photosynthesis begins around day 5 when the chloroplasts are activated (Dung et al., 2010). Thus, the increased structural carbohydrate in sprout green forage would change the quantity of the other nutrients such as protein in a higher percentage.

However, the present study observed that the CP content of treatment groups T2 and T4 is significantly higher than the other HMF irrigated with tap water (T1 and T3). It may be due to the absorption of nitrates of nutrient solution correlates with the metabolism of nitrogenous compounds from storage carbohydrates, leading to increasing CP content. It is because the radicle (root) extends from day 4, allowing for mineral absorption, resulting in rapid changes in ash and protein contents (Morgan et al. as cited in Naik et al., 2015, p. 4). The highest detergent fibers (NDF and ADF) content was found in popcorn irrigated with clean tap water (T1). NDF in forages represents the indigestible and slowly digestible components in the plant cell wall. Cellulose and hemicellulose are quantitatively the most prominent, essentially indigestible, and resistant to microbial infection in the rumen of ruminants due to their complex chemical structure. Lignin and cutin, the 
other main components of NDF, are nearly indigestible in both the rumen and the lower intestines. ADF is similar to NDF but without hemicellulose, containing cellulose, lignin, and cutin.

Generally, there were significant differences $(P<0.05)$ in the chemical content of hydroponics fodder maize germinated from feed corn (T4) irrigated with nutrient solution compared to the popcorn irrigated with tap water (T1) and nutrient solution (T2). However, Agius et al. (2019) emphasized that hydroponic fodders used the resources and energy of the seeds, no additional nutrients were needed for the production. Some reports on a slight increase in the nutrient content of the sprouts, but this does not rationalize the additional cost of using a nutrient solution instead of freshwater (Dung et al., 2010; Sneath \& Mclntosh, 2003). On top of that, higher urea concentrations did not have a beneficial effect on growth and yield; instead, an adverse effect was observed on hydroponic maize production (Aruna et al., 2018). Thus, using tap water irrigation might save money in the long run for smallholder livestock farmers.

Although feed corn had better nutritional value than popcorn, the root mat of treatment groups T3 and T4 was moldy, not detected in treatment groups $\mathrm{T} 1$ and T2. The mold growth might be related to the quality of the grain because all grains were managed with a standardized method. The moldy sprouts have been shown to reduce growth performance and are a known cause of animal death (Kumar et al., 2018).
In addition, the fresh yield of the crops is essential for successful hydroponic fodder production. Germination of $1 \mathrm{~kg}$ popcorn would produce approximately $2.5 \mathrm{~kg}$ of fresh fodder (T1 and T2) compared to $1 \mathrm{~kg}$ of feed corn that grew about $1.5 \mathrm{~kg} \mathrm{HMF}$ sprouted from popcorn had a thicker mat of roots and longer than the feed corn. Thus, popcorn with a higher conversion ratio and the germination rate was used to grow HMF with the open-air hydroponic system.

\section{Chemical Composition between Conventional Fodder and Hydroponic Maize Fodder}

The total percentage of the chemical composition in green fodders was summarized in Table 4. The result showed a higher DM composition in Napier grass $(P<0.05)$. The $\mathrm{CP}$ content presently denoted in HMF was $12.28 \%$ higher than the Napier grass $(P<0.05)$. Napier grass showed significantly higher OM content, $90.99 \%$ compared to $88.85 \%$ in HMF. Besides, higher NDF was observed in Napier grass $(P<0.05)$. In addition, ADF and ADL composition were significantly higher in Napier grass, which possessed approximately 3 and 14 times higher than HMF, respectively.

$\mathrm{DM}$ is a primary indicator of the number of nutrients available to the animal in a feed. Livestock voluntarily consume a certain amount of DM per day (measured in $\mathrm{kg}$ /day) to maintain health, growth, and production (Naik et al., 2014). The values of DM reported by Lounglawan et al. (2014) as $18.93 \%$ in Napier grass harvested at 
$10 \mathrm{~cm}$ height on the $60^{\text {th }}$ day, Ghani et al. Gebremedhin (2015) in HMF as $18.30 \%$ and (2017) as $13.04 \%$ in which Napier grass was harvested manually from pasture at the age of 8 weeks, Rahman et al. (2014) as $20.79 \%$ were lower than the present finding, $26.01 \%$. In the present investigation, the DM content in HMF was $24.75 \%$, lower than Napier grass because of high moisture content. However, this value was higher than the results reported by Naik et al. (2014) and

$18.48 \%$, respectively. Higher DM content in HMF was reported if harvested at an older age and cultivated in a nutrient solution. A study conducted by Thadchanamoorthy and Pramalal (2012) reported higher DM content as $26.07 \%$ in 10 days old $\mathrm{HMF}$, while Adebiyi et al. (2018) noted 25.00\% DM content in 7 days old HMF, which was cultivated with nutrient solution.

Table 4

Chemical composition of green fodder

\begin{tabular}{ccc}
\hline $\begin{array}{c}\text { Parameters } \\
(\% \text { of DM })\end{array}$ & $\begin{array}{c}\text { Conventional Napier green } \\
\text { fodder }\end{array}$ & $\begin{array}{c}\text { Hydroponic } \\
\text { maize fodder }\end{array}$ \\
DM & $\mathrm{n}=32$ & $\mathrm{n}=32$ \\
CP & $26.01 \pm 0.38^{\mathrm{b}}$ & $24.75 \pm 0.20^{\mathrm{a}}$ \\
OM & $7.22 \pm 0.09^{\mathrm{a}}$ & $12.28 \pm 0.25^{\mathrm{b}}$ \\
NDF & $90.99 \pm 0.10^{\mathrm{b}}$ & $88.85 \pm 0.35^{\mathrm{a}}$ \\
ADF & $75.66 \pm 0.24^{\mathrm{b}}$ & $64.02 \pm 0.45^{\mathrm{a}}$ \\
ADL & $48.92 \pm 0.38^{\mathrm{b}}$ & $17.90 \pm 0.51^{\mathrm{a}}$ \\
Hemicellulose & $43.55 \pm 0.32^{\mathrm{b}}$ & $3.49 \pm 0.40^{\mathrm{a}}$ \\
Cellulose & $26.80 \pm 0.60^{\mathrm{a}}$ & $46.09 \pm 0.92^{\mathrm{b}}$ \\
Ash & $5.38 \pm 0.66^{\mathrm{a}}$ & $14.41 \pm 0.70^{\mathrm{b}}$ \\
\hline
\end{tabular}

Note. $\mathrm{DM}=$ Dry matter; $\mathrm{CP}=$ Crude protein; $\mathrm{OM}=$ Organic matter; $\mathrm{NDF}=$ Neutral detergent fiber; $\mathrm{ADF}=$ Acid detergent fiber; $\mathrm{ADL}=$ Acid detergent lignin; $\mathrm{n}=$ Number of samples; All analyses are mean \pm standard error of means (SEM); Means with different superscript letters in a row are significantly different $(P<0.05)$

The CP content presently denoted in is encouraging to compare the findings of HMF was $12.28 \%$ higher than the Napier this study with the results by Jemimah et al. grass $(P<0.05)$. CP in feeding stuff includes $\quad(2018)$, who recorded $10.55 \% \mathrm{CP}$ content the true protein containing amino acids and of HMF with an 8-days growth period but non-protein nitrogenous compounds such lower than the CP content reported by several as amides. HMF was preferred as a source studies as ranged from $13.30 \%$ to $16.54 \%$ of quality forage for livestock because it (Adebiyi et al., 2018; Kide et al., 2015; Naik has a high protein (Ndaru et al., 2020). It et al., 2012, 2013, 2014; Thadchanamoorthy 
\& Pramalal, 2012). The minor differences in minor results are probably due to the variety and quality of seed used, light intensity, quality of the irrigation water, and germination time (Kaouche-Adjlanea et al., 2016). A study showed that HMF would have higher CP content $(24.07 \mathrm{~g} / 100 \mathrm{~g})$ when harvested on the eighth day (Islam et al., 2016). However, the current study produced outdoor HMF exposed to high humidity, unlike those grown in a greenhouse. High humidity is one of the promoting factors of mold growth at the mat of roots when the length of the growth period increases. Generally, a concentration of $6-8 \% \mathrm{CP}$ in the basal forage is a threshold for a response by ruminant livestock to $\mathrm{N}$ supplements (Mathis et al., 2000). The CP content of Napier grass investigated in the present study was $7.22 \%$. The value was higher than the findings obtained by Zailan et al. (2016) in common Napier grass harvested at an interval of 8 weeks as $6.44 \%$ and Ghani et al. (2017) as 3.88\%. The higher value of CP was reported by Rambau et al. (2016) in Napier grass leaves harvested at intermediate stage ( 8 weeks) as $140.4 \mathrm{~g} / \mathrm{kg}$ and Halim et al. (2013) in common Napier grass as $9.79 \%$, Lounglawan et al. (2014) as $8.87 \%$, Bayble et al. (2007) as $14.13 \%$ in Napier grass. The increment in enzymatic activities of nutrients can improve the $\mathrm{CP}$ content in HMF (Naik et al., 2013).

Napier grass showed significantly higher OM (90.99\%) content due to the application of fertilizer after each cutting $(P<0.05)$. The value of total ash $(11.22 \%)$ observed in the HMF of the present study is higher than the results reported by Naik et al. (2013) as a range of $1.75-3.80 \%$. The total ash content rises on account of the mineral absorption by roots throughout the sprouting phase. HMF had higher palatability due to the younger harvesting age that showed a decrease in the number and size of cell walls for the synthesis of structural carbohydrates (Bayble et al., 2007). The comparable crude fiber content was reported by a few studies in HMF as a range of 9.33-14.10\% (Gebremedhin, 2015; Kide et al., 2015; Naik et al., 2013). The higher value of crude fiber was reported by Adebiyi et al. (2018) as $14.77 \%$, and lower values were also reported by Thadchanamoorthy and Pramalal (2012) as $8.21 \%$ and Naik et al. (2014) as $6.37 \%$.

Although Napier grass showed a higher DM composition, the lower value of the CP justifies the need for HMF as alternative green fodders. In small ruminants, the amount of protein is more important than the quality of protein (Valente, 2016). In addition, the significantly lower NDF, $\mathrm{ADF}$, and ADL in HMF represent lower indigestible fibers, which predict HMF as more acceptable green fodder to animals.

\section{CONCLUSION}

The seven-days hydroponic maize fodder can be produced by using an open-air hydroponic system. The usage of nutrient solution is unnecessary to produce a similar fresh weight of fodder corresponding with sprouts irrigated with clean tap water show sizeable increment in nutrients such as crude protein, dry matter, and organic matter. It could be suggested that the outdoor-grown 
Whay Chuin Lim, Mohd Noor Hisham Mohd Nadzir, Mark Wen Han Hiew, Md. Shuhazlly Mamat, Muhamad Hazim Nazli and Shamarina Shohaimi

HMF is highly palatable due to its tenderness and younger harvesting age possess lower indigestible fibers (including NDF and ADF) compared to the conventional fodder. The highly nutritious HMF is fed as alternative green fodder because of the improved crude protein content. Although the dry matter of HMF was significantly lower than Napier grass, this shortcoming could be overcome by adding dry fodder or concentrate to the livestock diet.

From the agricultural economic aspect, it could be suggested that the outdoor-grown hydroponic maize fodder produced in this study might be an effective feeding solution to the current feeding management problem, which is the conventional labor-intensive cut-and-carry system faced by smallholders of the goat industry in Malaysia. This lowcost method can attract smallholders because it is less laborious, reuses the unutilized space, and does not require a greenhouse for the growth of HMF. Furthermore, there was no usage of chemical fertilizer and pesticide throughout the production of HMF results in a safe and contamination-free ruminant feed.

\section{ACKNOWLEDGMENTS}

This research was supported by a grant from Universiti Putra Malaysia (UPM/7002/1/GP/2017/9568200). In addition, we would like to thank the Department of Crop Science, Faculty of Agriculture, Universiti Putra Malaysia, for the guidance in using the FOSS DS2500 Near-Infrared Spectroscopy (NIRS).

\section{REFERENCES}

Abdullah, A. (2001). Nutritive value of barley fodder grown in a hydroponics system [Doctoral dissertation, Universiti Putra Malaysia]. Universiti Putra Malaysia Institutional Repository. http://psasir.upm.edu.my/id/ eprint/10568/1/FP_2001_24_A.pdf

Adebiyi, O. A., Adeola, A. T., Osinowo, O. A., Brown, D., \& Ng'Ambi, J. W. (2018). Effects of feeding hydroponics maize fodder on performance and nutrient digestibility of weaned pigs. Applied Ecology and Environmental Research, 16(3), 2415-2422. https://doi.org/10.15666/ aeer/1603_24152422

Agius, A., Pastorelli, G., \& Attard, E. (2019). Cows fed hydroponic fodder and conventional diet: Effects on milk quality. Archives Animal Breeding, 62(2), 517-525. https://doi.org/10.5194/aab-62-5172019

Al-Ajmi, A., Salih, A., Kadhim, I., \& Othman Y. (2009). Yield and water use efficiency of barley fodder produced under hydroponic system in GCC countries using tertiary treated sewage effluents. Journal of Phytology, 1(5), 342-348.

Al-Karaki, G. N., \& Al-Hashimi, M. (2012). Green fodder production and water use efficiency of some forage crops under hydroponic conditions. International Scholarly Research Notices, 2012, 924672. https://doi. org/10.5402/2012/924672

Aruna, P., Chakravarthi, M. K., Murthi, A. K., Lavanya, R., \& Siva, S. (2018). Effect of graded levels of urea fertilizer on growth and biomass yield of maize under low-cost hydroponic fodder production system. Forage Research, 43(4), 283-286.

Association of Official Analytical Chemists. (1990). Official methods of analysis (15th ed.). AOAC.

Bayble, T., Melaku, S., \& Prasad, N. K. (2007). Effects of cutting dates on nutritive value 
of Napier (Pennisetum purpureum) grass planted sole and in association with Desmodium (Desmodium intortum) or Lablab (Lablab purpureus). Livestock Research for Rural Development, 19(1), 120-136.

Dung, D. D., Godwin, I. R., \& Nolan, J. V. (2010). Nutrient content and in sacco degradation of hydroponic barley sprouts grown using nutrient solution or tap water. Journal of Animal and Veterinary Advances, 9(18), 2432-2435. https:// doi.org/10.3923/javaa.2010.2432.2436

Fazaeli, H., Golmohammadi, H. A., Shoayee, A. A., Montajebi, N. \& Mosharraf, S. (2011). Performance of feedlot calves fed hydroponics fodder barley. Journal Agricultural Science Technology, 13(3), 367-375.

Fazaeli, H., Golmohammadi, H. A., Tabatabayee, S. N., \& Asghari-Tabrizi, M. (2012). Productivity and nutritive value of barley green fodder yield in hydroponic system. World Applied Sciences Journal, 16(4), 531-539.

Francis, J. M., Apgar, G. A., Crandell, K. G., Handlos, G. C., \& Perry, E. B. (2018). The effects of hydroponic wheat fodder on fecal metabolites in equines. Journal of Equine Veterinary Science, 70, 84-90. https://doi.org/10.1016/j. jevs.2018.05.212

Gebremedhin, W. K. (2015). Nutritional benefit and economic value of feeding hydroponically grown maize and barley fodder for Konkan Kanyal goats. IOSR Journal of Agriculture and Veterinary Science, 8(7), 24-30.

Ghani, A. A. A., Shahudin, M. S., Zamri-Saad, M., Zuki, A. B., Wahid, H., Kasim, A., Salisi, M. S., \& Hassim, H. A. (2017). Enhancing the growth performance of replacement female breeder goats through modification of feeding program. Veterinary World, 10(6), 630-635. https://doi.org/10.14202/vetworld.2017.630-635

Halim, R. A., Shampazuraini, S., \& Idris, A. B. (2013). Yield and nutritive quality of nine Napier grass varieties in Malaysia. Malaysian Journal of Animal Science, 16(2), 37-44.

Hubballi, M., Nakkeeran, S., Raguchander, T., Anand, T., \& Samiyappan, R. (2010). Effect of environmental conditions on growth of Alternaria alternata causing leaf blight of noni. World Journal of Agricultural Sciences, 6(2), 171-177.

International Organization for Standardization. (2008). ISO 13906:2008: Animal feeding stuffs - Determination of acid detergent fibre (ADF) and acid detergent lignin (ADL) contents. https:// www.iso.org/standard/43032.html

International Seed Testing Association. (2016). International rules for seed testing. ISTA.

Islam, R., Jalal, N., \& Akbar, M. A. (2016). Effect of seed rate and water level on production and chemical analysis of hydroponic fodder. European Academic Research, 4(8), 6724-6753.

Jemimah, E. R., Gnanaraj, P. T., Muthuramalingam, T., Devi, T., \& Vennila, C. (2018). Productivity, nutritive value, growth rate, biomass yield and economics of different hydroponic green fodders for livestock. International Journal of Livestock Research, 8(9), 261-270. https://doi.org/10.5455/ ijlr.20171013104959

Kantale, R. A., Halburge, M. A., Deshmukh, A. D., Dhok, A. P., Raghuwanshi, D. S., \& Lende, S. R. (2017). Nutrient changes with the growth of hydroponics wheat fodder. International Journal of Science, Environment and Technology, 6(3), 1800-1803.

Kaouche-Adjlanea, S., Ahmed Serir, A., Bafdel, M., \& Benhacine, R. (2016). Techno-economic approach to hydroponic forage crops: Use for feeding dairy cattle herd. Journal of Applied Environmental and Biological Sciences, 6(3), 83-87.

Kide, W., Desai, B. G., \& Kumar, S. (2015). Nutritional improvement and economic value 
Whay Chuin Lim, Mohd Noor Hisham Mohd Nadzir, Mark Wen Han Hiew, Md. Shuhazlly Mamat, Muhamad Hazim Nazli and Shamarina Shohaimi

of hydroponically sprouted maize fodder. Life Sciences - International Research Journal, 2(2), 76-79.

Kumar, R., Mathur, M., Karnani, M., \& Dutt, S. (2018). Hydroponics: An alternative to cultivated green fodder: A review. Journal of Entomology and Zoology Studies, 6(6), 791-795.

Lounglawan, P., Lounglawan, W., \& Suksombat, W. (2014). Effect of cutting interval and cutting height on yield and chemical composition of King Napier grass (Pennisetum purpureum $\mathrm{x}$ Pennisetum americanum). APCBEE Procedia, 8, 27-31. https://doi.org/10.1016/j. apcbee.2014.01.075

Mathis, C. P., Cochran, R. C., Heldt, J. S., Woods, B. C., Abdelgadir, I. E. O., Olson, K. C., Titgemeyer, E. C., \& Vanzant, E. S. (2000). Effects of supplemental degradable intake protein on utilization of medium-to low-quality forages. Journal of Animal Science, 78(1), 224232. https://doi.org/10.2527/2000.781224x

Molla, A., \& Sharaiha, R. K. (2010). Competition and resource utilization in mixed cropping of barley and durum wheat under different moisture stress levels. World Journal of Agricultural Sciences, 6(6), 713-719.

Naik, P. K., Dhuri, R. B., Karunakaran, M., Swain, B. K., \& Singh, N. P. (2013). Hydroponics technology for green fodder production. Indian Dairyman, 65(3), 54-58.

Naik, P. K., Dhuri, R. B., Karunakaran, M., Swain, B. K., \& Singh, N. P. (2014). Effect of feeding hydroponics maize fodder on digestibility of nutrients and milk production in lactating cows. The Indian Journal of Animal Sciences, 84(8), 880-883.

Naik, P. K., Dhuri, R. B., Swain, B. K., \& Singh, N. P. (2012). Nutrient changes with the growth of hydroponics fodder maize. Indian Journal of Animal Nutrition, 29(2), 161-163.
Naik, P. K., Swain, B. K., \& Singh, N. P. (2015). Production and utilisation of hydroponics fodder. Indian Journal of Animal Nutrition, 32(1), 1-9.

Ndaru, P. H., Huda, A. N., Prasetyo, R. D., Shofiatun, U., Nuningtyas, Y. F., \& Ndaru, R. K. (2020). Providing high quality forages with hydroponic fodder system. In IOP Conference Series: Earth and Environmental Science (Vol. 478, No. 1, p. 012054). IOP Publishing. https://doi. org/10.1088/1755-1315/478/1/012054

Peer, D. J., \& Leeson, S. (1985). Feeding value of hydroponically sprouted barley for poultry and pigs. Animal Feed Science and Technology, 13(34), 183-190. https://doi.org/10.1016/03778401(85)90021-5

Rahman, M. M., Abdullah, R. B., Wan Khadijah, W. E., Nakagawa, T., \& Akashi, R. (2014). Feed intake and growth performance of goats offered Napier grass (Pennisetum purpureum) supplemented with concentrate pellet and soya waste. Sains Malaysiana, 43(7), 967-971.

Rambau, M. D., Fushai, F., \& Baloyi, J. J. (2016). Productivity, chemical composition and ruminal degradability of irrigated Napier grass leaves harvested at three stages of maturity. South African Journal of Animal Science, 46(4), 398408. https://doi.org/10.4314/sajas.v46i4.8

Sneath, R., \& McIntosh, F. (2003). Review of hydroponic fodder production for beef cattle. https://cpb-us-east-1-juc1ugur1qwqqqo4. stackpathdns.com/blogs.cornell.edu/dist/e/4211/ files/2014/05/Hydroponicfodder-article11wpnm0.pdf

Thadchanamoorthy, S., \& Pramalal, V. J. C. (2012). Evaluation of hydroponically grown maize as a feed source for rabbits. http://agri.pdn.ac.lk/ ext_staff/upload/publications/publication_249 dept_5_fbe225af2b33ebfaab9e85855d643937. pdf\#page $=17$ 
Trubey, C. R., Rhykerd, C. L., Noller, C. H., Ford, D. R., \& George, J. R. (1969). Effect of light, culture solution, and growth period on growth and chemical composition of hydroponically produced oat seedlings. Agronomy Journal, 61(5), 663-665. https://doi.org/10.2134/agronj1969.00 $021962006100050003 x$

Valente, T. N. P., da Silva Lima, E., dos Santos, W. B. R., Cesario, A. E. S., Tavares, C. A. J., \& de Freitas, M.A. M. (2016). Ruminal microorganism consideration and protein used in the metabolism of the ruminants: A review. African Journal of Microbiology Research, 10(14), 456-464. https:// doi.org/10.5897/AJMR2016.7627

Zailan, M. Z., Yaakub, H., \& Jusoh, S. (2016). Yield and nutritive value of four Napier (Pennisetum purpureum) cultivars at different harvesting ages. Agriculture and Biology Journal of North America, 7(5), 213-219. https://doi.org/10.5251/ abjna.2016.7.5.213.219 
